\title{
Groundwater Quality in the High Plains Aquifer
}

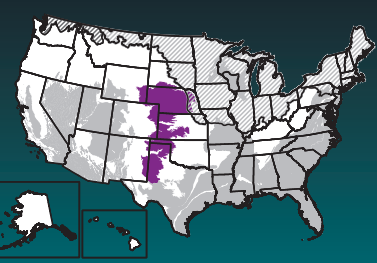

Groundwater provides nearly 50 percent of the Nation's drinking water. To help protect this vital resource, the U.S. Geological Survey (USGS) National Water-Quality Assessment (NAWQA) Project assesses groundwater quality in aquifers that are important sources of drinking water. The High Plains aquifer constitutes one of the important aquifers being evaluated.

\section{Background}

The High Plains aquifer underlies an area of about 169,000 square miles, which is populated by about 2 million people in parts of eight western states (Colorado, Kansas, Nebraska, New Mexico, Oklahoma, Texas, South Dakota, and Wyoming). The aquifer ranks 13th in the Nation as a source of groundwater for public supply, with about 390 million gallons per day pumped for this use in 2000 (Maupin and Barber, 2005; Arnold and others, 2020a). The aquifer is also extensively used for agriculture, ranking first in the Nation as a source of groundwater for irrigation, with water pumped for irrigation markedly higher than for public supply (17,000 million gallons per day). Land use overlying the High Plains aquifer is composed primarily of natural land cover (including rangeland; 59 percent) and agricultural land (37 percent) with relatively small areas of urban and other developed land (4 percent; Homer and others, 2015). About 20 percent of the Nation's irrigated agricultural land overlies the High Plains aquifer. The four largest cities that lie within the aquifer's overlying land are Amarillo, Lubbock, and Midland, Texas, and Cheyenne, Wyoming. Most of the population of the region reside in smaller cities and towns and rural areas. Urban development is much less widespread than agriculture over the High Plains aquifer.

The extensive area of the High Plains aquifer includes a wide range of topography and climate and as a result is commonly divided into three geographic subregions: the Northern, Central, and Southern High Plains (McMahon and others, 2007). Precipitation generally decreases from east to west, and temperatures increase from north to south (Thornton and others, 1997). The aquifer is described in detail by McMahon and others (2007) and summarized here. The High Plains aquifer is generally unconfined and is composed of Tertiary and Quaternary near-surface deposits that form six hydraulically connected hydrogeologic units. The Ogallala Formation, which has the largest areal extent of these units, consists primarily of unconsolidated clay, silt, sand, and gravel with locally cemented carbonate zones. Older sedimentary bedrock units underlie the aquifer. Evaporation rates are some of the highest in the Nation, owing to high summer air temperatures and persistent winds. Because evaporation rates exceed precipitation across much of the study area, little water recharges the aquifer. Recharge that does occur is primarily by infiltration of irrigation water; diffuse infiltration from precipitation; focused infiltration of storm and irrigation water runoff through streambeds, playas, and other topographic depressions; and upward movement of water from underlying aquifers. Discharge occurs primarily by irrigation-well pumping, discharge to streams and underlying aquifers, flow across the eastern boundary of the aquifer, and evapotranspiration. Regional groundwater flow is generally from west to east. Substantial water-level changes have occurred in the High Plains aquifer. Because groundwater withdrawals have greatly exceeded recharge rates across much of the aquifer, water-level declines are common across parts of Kansas, Oklahoma, New Mexico, and Texas.

Groundwater quality in the High Plain aquifer was evaluated in 2015 and 2016 by sampling 80 public-supply wells that were spatially distributed across the aquifer. For this discussion, we define the study area as the depth zone used for public supply in the High Plains aquifer. Water-quality data collected from the spatially distributed wells (7 in Colorado, 11 in Kansas, 32 in Nebraska, 4 in New Mexico, 4 in Oklahoma, and 5 in Wyoming were sampled in 2015; 17 were sampled in Texas in 2016) are representative of water quality in the study area, following the approach described by Belitz and others (2010). This approach allows for the estimation of the percentage of the study area with concentrations that are high, moderate, and low with respect to constituent benchmarks. The accuracy of the estimates depends on the distribution and number of wells, not the size of the area (Belitz and others, 2010). The wells ranged from 54 to 812 feet deep (averaging 282 feet deep) and were typically open to the aquifer across a range of depth intervals ranging from 10 to 375 feet (averaging about 84 feet). Samples were analyzed for a large number of waterquality constituents derived from natural and human sources.

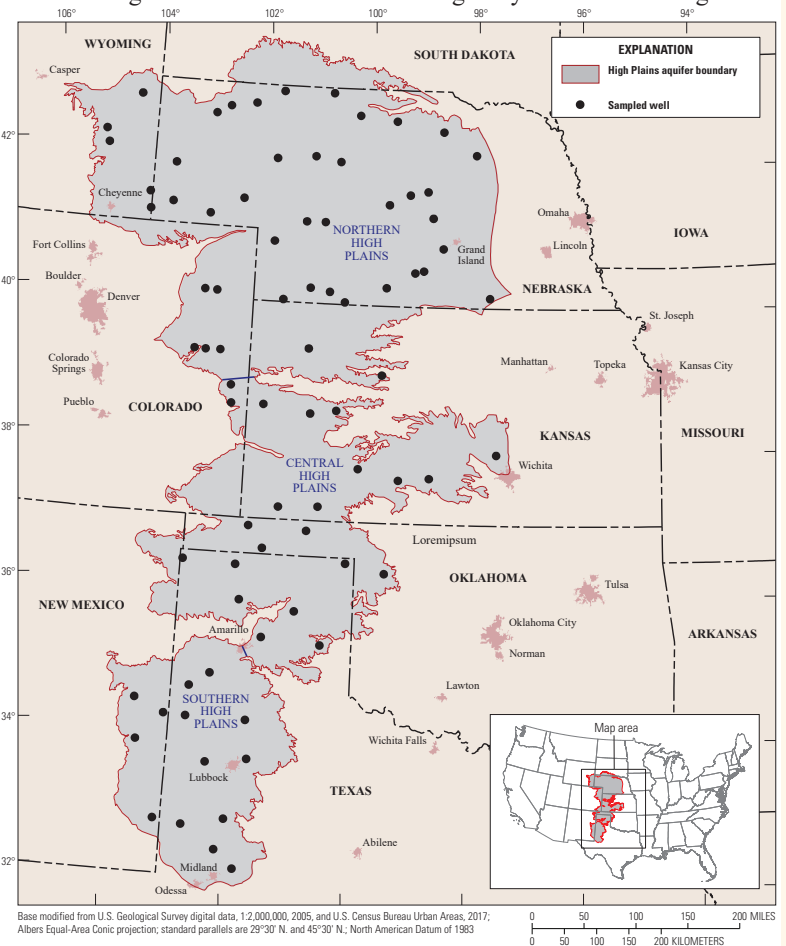

Overview of Water Quality

\section{Inorganic constituents}

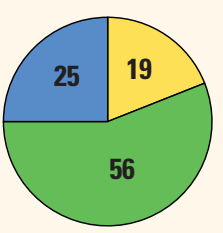

Organic constituents

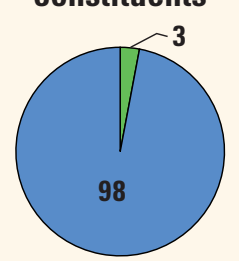

CONSTITUENT CONCENTRATIONS

$\bigcirc$ High $\bigcirc$ Moderate $\bigcirc$ Low or not detected

Values are a percentage of the study area with concentrations in the three specified categories. Percentages might not sum to 100 because of rounding.

Principal Aquifer Studies (Burow and Belitz, 2014) are designed to evaluate groundwater used for public supply prior to any treatment. Groundwater quality is assessed by comparing concentrations to benchmarks established for drinking-water quality. Benchmarks and definitions of high, moderate, and low relative concentrations are discussed at the bottom of page 3 . Water from 81 percent of the wells sampled did not have high concentrations relative to benchmarks of any constituent measured.

Many inorganic constituents are naturally present in groundwater. The concentrations of inorganic constituents can be affected by natural processes as well as by human activities. One or more inorganic constituents with human-health benchmarks were detected at high concentrations in about 19 percent of the study area and at moderate concentrations in about 56 percent.

Organic constituents derived from human activities are used in household, business, industrial, and agricultural products. They can enter the environment through normal usage, spills, or improper disposal. Organic constituents with human-health benchmarks were detected at moderate concentrations in 3 percent of the study area. 


\section{Results: Groundwater Quality at the Depth Zone Used for Public Supply in the High Plains Aquifer}

\section{INORGANIC CONSTITUENTS}
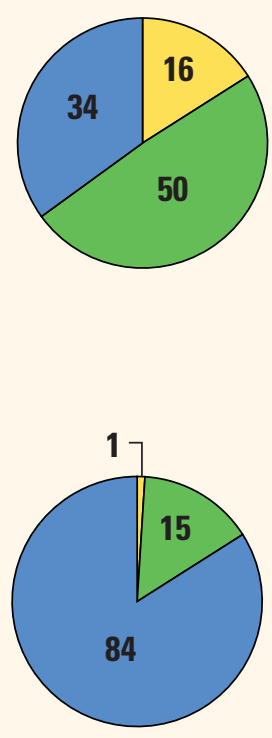

\section{Radioactive constituents}
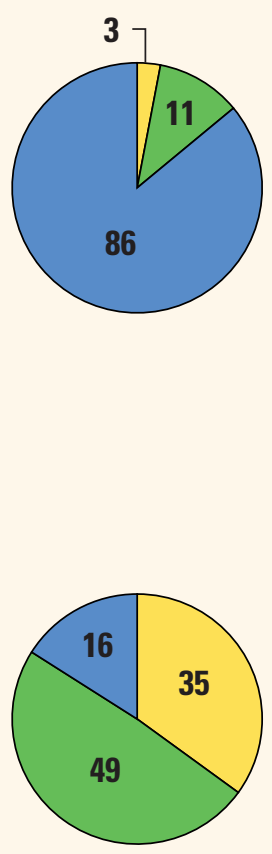

\section{Inorganic Constituents With Human-Health Benchmarks}

Trace elements and major and minor ions are naturally present in the minerals of rocks, soils and sediments, and in the water that comes into contact with those materials. Samples were analyzed for 34 trace elements and major and minor ions, of which 22 have human-health benchmarks (healthbased screening level [HBSL] benchmarks were updated in 2018 to include aluminum, cobalt, and iron). Constituents from this group were detected at high concentrations in about 16 percent of the study area (the depth zone used for public supply) and at moderate concentrations in about 50 percent. Uranium and arsenic were the trace elements most frequently detected at high concentrations ( 8 and 6 percent, respectively). Uranium, arsenic, and fluoride were detected at moderate concentrations in about 15, 44, and 13 percent of the study areas, respectively. Strontium was detected at high or moderate concentrations in about 11 percent of the study area.

Radioactivity is the release of energy or energetic particles during the spontaneous decay of unstable atoms. Humans are continuously exposed to small amounts of natural radioactivity. Most of the radioactivity in groundwater comes from the decay chain of isotopes of uranium and thorium that are naturally present in minerals in aquifer materials. Samples were analyzed for eight radioactive constituents, of which four have human-health benchmarks. Radioactive constituents, primarily resulting from gross-alpha activity, were present at high levels in about 1 percent of the study area and at moderate levels in about 15 percent of the study area.

Nutrients are naturally present at low concentrations in groundwater; high and moderate concentrations (relative to human-health benchmarks) generally result from human activities. Samples were analyzed for five nutrients, of which two (nitrate and nitrite) have human-health benchmarks. Common sources of nutrients, aside from soils, include fertilizer applied to crops and landscaping, seepage from septic systems, and human and animal waste. Nitrate was measured at high concentrations in about 3 percent of the study area and at moderate concentrations in about 11 percent. Previous studies have noted that nitrate concentrations in the High Plains aquifer are higher in shallow groundwater relative to deeper and older groundwater (Bruce and Oelsner, 2001; McMahon, 2001; Gurdak and others, 2009).

\section{Inorganic Constituents and Field Measurements With Non-Health Benchmarks}

(Not included in water-quality overview charts shown on the front page)

Some constituents affect the aesthetic properties of water, such as taste, color, and odor, or can create nuisance problems, such as staining and scaling. The benchmarks used for these constituents were non-regulatory secondary maximum contaminant level (SMCL) benchmarks established for public drinking water. Some constituents, such as manganese and fluoride, have human-health benchmarks and SMCLs. Samples were analyzed for 11 constituents that have SMCLs. One or more of these were present at high concentrations relative to the SMCL in about 35 percent of the study area and at moderate concentrations in about 49 percent.

Total dissolved solids (TDS) concentration is a measure of the salinity of the groundwater based primarily on concentrations of ions. All water naturally contains TDS because of the weathering and dissolution of minerals in rocks and sediments. Concentrations of TDS can be high as a result of natural factors or human activities, such as applications to the land surface of road salt, fertilizers, or other chemicals in urban or agricultural areas. Most of the study area had high (26 percent) or moderate (54 percent) concentrations of TDS. Fluoride and sulfate were present at high concentrations in about 15 and 10 percent of the study area, respectively, and at moderate concentrations in 18 and 11 percent, respectively.

Anoxic conditions in groundwater (low amounts of dissolved oxygen) can result in the release of iron and manganese in minerals to the groundwater. Manganese and iron were measured at high concentrations relative to the SMCL in about 11 and 1 percent, respectively, of the study area.

Groundwater $\mathrm{pH}$ has an SMCL range of 6.5 to 8.5. In the High Plains aquifer, $\mathrm{pH}$ was greater than 8.5 , which is alkaline, in about 1 percent of the study area. 


\section{Results: Groundwater Quality at the Depth Zone Used for Public Supply in the High Plains Aquifer}

\section{ORGANIC CONSTITUENTS}

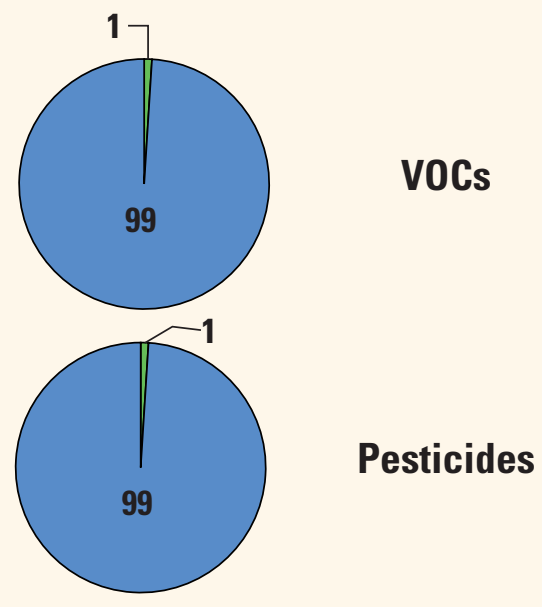

\section{Volatile Organic Compounds With Human-Health Benchmarks}

Volatile organic compounds (VOCs) are present in many household, commercial, industrial, and agricultural products and are characterized by their tendency to volatilize (evaporate). Samples were analyzed for 85 VOCs, of which 51 have human-health benchmarks. VOCs were detected at moderate concentrations in 1 percent of the study area (based on trichloroethylene-TCE-concentration).

\section{Pesticides With Human-Health Benchmarks}

Pesticides, including herbicides, insecticides, and fungicides, are applied to crops, gardens and lawns, around buildings, and along roads to help control unwanted vegetation (weeds), insects, fungi, and other pests. Samples were analyzed for 225 pesticide compounds (pesticides and their breakdown products), of which 119 have human-health benchmarks. Pesticide compounds were detected at moderate concentrations in 1 percent of the study area (based on detections of the herbicide atrazine).

\section{BENCHMARKS FOR EVALUATING GROUNDWATER OUALITY}

The USGS NAWQA Project uses benchmarks established for drinking water to provide context for evaluating the quality of untreated groundwater. The quality of water received by consumers can be different from results presented herein because after withdrawal, groundwater may be treated prior to delivery. Federal regulatory benchmarks for protecting human health are used for this evaluation of water quality when available. Otherwise, non-regulatory human-health benchmarks and nonregulatory aesthetic benchmarks are used. Not all constituents analyzed have benchmarks and, thus, are not considered in this context. Human-health benchmarks are available for 28 of 55 inorganic constituents and properties and 170 of 310 organic constituents.

PERCENTAGE OF STUDY AREA

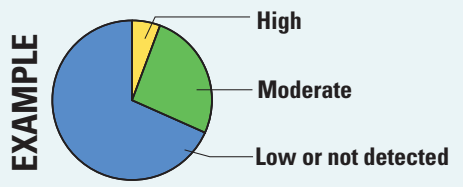

Values are a percentage of the study area with concentrations in the three specified categories. Percentages might not sum to 100 because of rounding.

Concentrations are considered high if they are greater than a human-health benchmark (Norman and others, 2018) or SMCL. For inorganic constituents, concentrations are moderate if they are greater than one-half of a benchmark. For organic constituents, concentrations are moderate if they are greater than one-tenth of a benchmark; this lower threshold is used because organic constituents are generally less prevalent and have smaller concentrations relative to benchmarks than inorganic constituents (Toccalino and others, 2004).

\section{Benchmark Type and Value for Selected Constituents}

This table presents benchmarks for those constituents detected at high concentrations in the High Plains aquifer. Benchmark types are regulatory U.S. Environmental Protection Agency (EPA) maximum contaminant levels (MCLs), non-regulatory health-based screening levels (HBSLs), and non-regulatory EPA secondary maximum contaminant levels (SMCLs).

[ppb, part per billion or microgram per liter $(\mu \mathrm{g} / \mathrm{L})$; ppm, part per million or milligram per liter $(\mathrm{mg} / \mathrm{L})$; $\mathrm{pCi} / \mathrm{L}$, picocurie per liter]

\begin{tabular}{|c|c|c|c|c|c|}
\hline \multirow{2}{*}{ Constituent } & \multicolumn{2}{|c|}{ Benchmark } & \multirow{2}{*}{ Constituent } & \multicolumn{2}{|c|}{ Benchmark } \\
\hline & Type & Value & & Type & Value \\
\hline Arsenic & MCL & $10 \mathrm{ppb}$ & Total dissolved solids (TDS) & SMCL & $500 \mathrm{ppm}$ \\
\hline Fluoride & MCL & $4 \mathrm{ppm}$ & Fluoride & SMCL & $2 \mathrm{ppm}$ \\
\hline Strontium & HBSL & $4,000 \mathrm{ppb}$ & Sulfate & SMCL & $250 \mathrm{ppm}$ \\
\hline Manganese & HBSL & $300 \mathrm{ppb}$ & Chloride & SMCL & $250 \mathrm{ppm}$ \\
\hline Uranium & MCL & $30 \mathrm{ppb}$ & Manganese & SMCL & $50 \mathrm{ppb}$ \\
\hline Nitrate as nitrogen & MCL & $10 \mathrm{ppm}$ & Iron & SMCL & $300 \mathrm{ppb}$ \\
\hline Gross-alpha activity & MCL & $15 \mathrm{pCi} / \mathrm{L}$ & $\mathrm{pH}$ & SMCL & $6.5-8.5$ \\
\hline
\end{tabular}


Constituents With Moderate and High Concentration Vary by Region

Inorganic constituents with human-health benchmarks and constituents with secondary nonhealth benchmarks commonly were measured at high and moderate concentrations in the High Plains aquifer. The most prevalent of these constituents with moderate or high concentrations relative to human-health benchmarks were arsenic, fluoride, and uranium, and the most prevalent relative to secondary non-health benchmarks was TDS. The distribution of these constituents, however, varied across the Northern, Central, and Southern High Plains aquifer subregions. High concentrations of TDS, arsenic, and fluoride were most common in the Southern High Plains. High and moderate concentrations of uranium were less common overall but were, conversely, more common in the Northern High Plains. These differences in water quality across the High Plains aquifer might reflect differences in the composition of rocks and sediments that compose the aquifer, aquifer flow-path characteristics, aquifer geochemical conditions, and other factors. Previous studies have noted higher concentrations of constituents such as arsenic and fluoride that often correlate with higher TDS concentrations in the Southern High Plains and attributed the high concentrations to the upward movement of saline water from the underlying Dockum aquifer (Nativ and Smith, 1987; Scanlon and others, 2009). High concentrations of uranium have been previously noted throughout the High Plains aquifer and were correlated with nitrate concentrations, particularly in shallow groundwater (Nolan and Weber, 2015).

By MaryLynn Musgrove

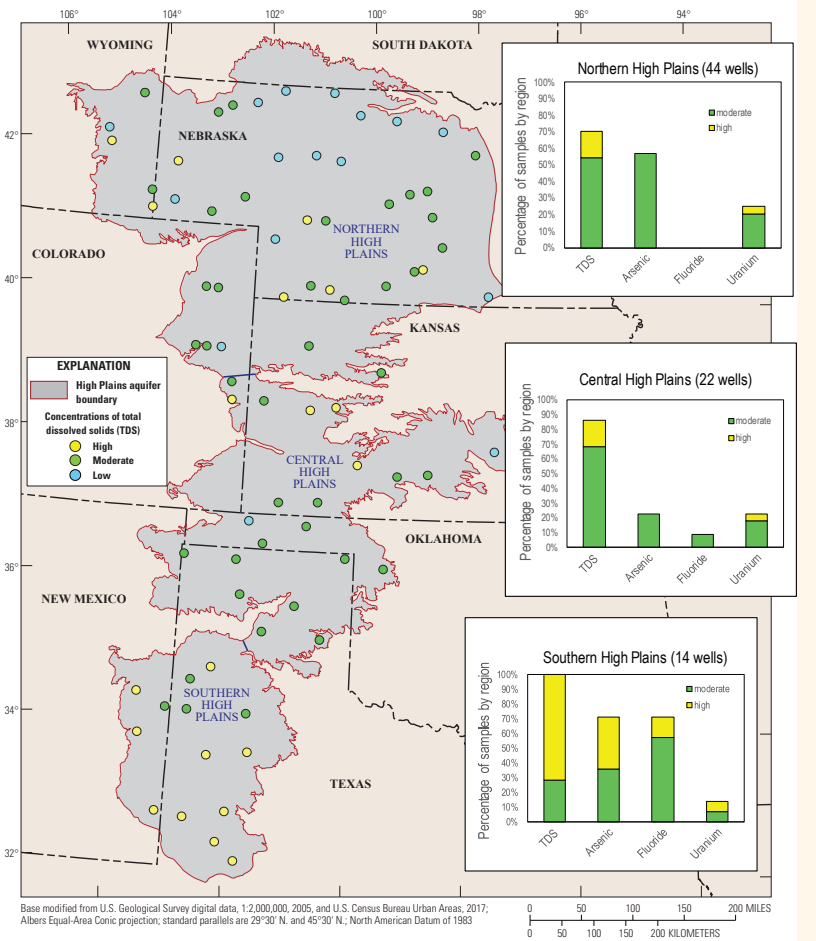

\section{REFERENCES CITED}

Arnold, T.L., Bexfield, L.M., Musgrove, M., Erickson, M.L., Kingsbury, J.A., Degnan, J.R., Tesoriero, A.J., Kulongoski, J.T., and Belitz, K., 2020a, Groundwater-quality and select quality-control data from the National Water-Quality Assessment Project, January through December 2016, and previously unpublished data from 2013 to 2015: U.S. Geological Survey Data Series 1124, 135 p., https://doi.org/10.3133/ds1124.

Arnold, T.L., Sharpe, J.B., Bexfield, L.M., Musgrove, M., Erickson, M.L., Kingsbury, J.A., Degnan, J.R., Tesoriero, A.J., Kulongoski, J.T., and Belitz, K., 2020b, Datasets from groundwater-quality and select quality-control data from the National Water-Quality Assessment Project, January through December 2016, and previously unpublished data from 2013 to 2015: U.S. Geological Survey data release, https://doi.org/10.5066/P9W4RR74.

Belitz, K., Jurgens, B., Landon, M.K., Fram, M.S., and Johnson, T., 2010, Estimation of aquifer scale proportion using equal area grids-Assessment of regional scale groundwater quality: Water Resources Research., v. 46, 14 p., https://doi.org/10.1029/2010WR009321.

Bruce, B.W., and Oelsner, G.P., 2001, Contrasting water quality from paired domestic/public supply wells, Central High Plains: Journal of the American Water Resources Association, v. 37, no. 5, p. 1389-1403, https://pubs.er.usgs.gov/publication/70023454.

Burow, K.R., and Belitz, K., 2014, Groundwater studies_-Principal aquifer surveys: U.S. Geological Survey Fact Sheet 2014-3024, 2 p., https://doi.org/10.3133/fs20143024.

DeSimone, L.A., McMahon, P.B., and Rosen, M.R., 2014, The quality of our Nation's waters-Water quality in principal aquifers of the United States, 1991-2010: U.S. Geological Survey Circular 1360, 151 p., https://doi.org/10.3133/cir1360.

Gurdak, J.J., McMahon, P.B., Dennehy, K.F., and Qi, S.L., 2009, Water quality in the High Plains aquifer, Colorado, Kansas, Nebraska, New Mexico, Oklahoma, South Dakota, Texas, and Wyoming, 1999-2004: U.S. Geological Survey Circular 1337, 63 p., https://doi.org/10.3133/cir1337.

Homer, C.G., Dewitz, J.A., Yang, L., Jin, S., Danielson, P., Xian, G., Coulston, J., Herold, N.D., Wickham, J.D., and Megown, K., 2015, Completion of the 2011 National Land Cover Database for the conterminous United States-Representing a decade of land cover change information: Photogrammetric Engineering and Remote Sensing, v. 81, no. 5, p. 345-354, https://pubs.er.usgs.gov/publication/70146301.

Maupin, M.A., and Barber, N.L., 2005, Estimated withdrawals from principal aquifers in the United States, 2000: U.S. Geological Survey Circular 1279, 46 p., https://doi.org/10.3133/cir1279.

McMahon, P.B., 2001, Vertical gradients in water chemistry in the Central High Plains aquifer, southwestern Kansas and Oklahoma panhandle, 1999: U.S. Geological Survey Water Resources Investigations Report 01-4028, 47 p., https://doi.org/10.3133/wri014028.

McMahon, P.B., Dennehy, K.F., Bruce, B.W., Gurdak, J.J., and Qi, S.L., 2007, Water-quality assessment of the High Plains Aquifer, 1999-2004: U.S. Geological Survey Professional Paper 1749, 136 p., https://doi.org/10.3133/pp1749.

Nativ, R., and Smith, D.A., 1987, Hydrogeology and geochemistry of the Ogallala aquifer, Southern High Plains: Journal of Hydrology, v. 91, nos. 3-4, p. 217-253, https://doi.org/10.1016/0022-1694(87)90206-X.

Nolan, J., and Weber, K.A., 2015, Natural uranium contamination in major U.S. aquifers linked to nitrate: Environmental Science and Technology Letters, v. 2, no. 8, p. 215-220, https://doi.org/10.1021/acs.estlett.5b00174.

Norman, J.E., Toccalino, P.L., Morman, S.A., 2018, Health-based screening levels for evaluating water-quality data (2d ed.): U.S. Geological Survey National Water-Quality Assessment Program web page, https://doi.org/10.5066/F71C1TWP.

Scanlon, B.R., Nicot, J.P., Reedy, R.C., Kurtzman, D., Mukherjee, A., and Nordstrom, D.K., 2009, Elevated naturally occurring arsenic in a semiarid oxidizing system, Southern High Plains aquifer, Texas, USA: Applied Geochemistry, v. 24, no. 11, p. 2061-2071, https://doi.org/10.1016/j.apgeochem.2009.08.004.

Toccalino, P.L., Norman, J.E., Phillips, R.H., Kauffman, L.J., Stackelberg, P.E., Nowell, L.H., Krietzman, S.J., and Post, G.B., 2004, Application of health-based screening levels to ground-water quality data in a state-scale pilot effort: U.S. Geological Survey Scientific Investigations Report 2004-5174, 64 p., https://doi.org/10.3133/sir20045174.

Thornton, P.E., Running, S.W., and White, M.A., 1997, Generating surfaces of daily meteorological variables over large regions of complex terrain: Journal of Hydrology, v. 190, nos. 3-4, p. 214-251, https://doi.org/10.1016/S0022-1694(96)03128-9.

\section{Principal Aquifer Surveys}

The USGS NAWQA Project has been assessing the quality of groundwater since 1991. The NAWQA studies include Land Use Studies (LUS), Major Aquifer Studies (MAS), and Principal Aquifer Studies (PAS). These three study types are based on sampling networks of wells distributed across an area of interest. The LUS networks typically consist of observation wells that are relatively shallow; MAS networks typically consist of domestic-supply wells that are intermediate in depth; and PAS networks typically consist of public-supply wells that are relatively deep. A national synthesis of shallow and intermediate depth groundwater quality was reported by DeSimone and others (2014). A regional synthesis of water quality for the High Plains aquifer was reported by McMahon and others (2007) and Gurdak and others (2009). This fact sheet provides a summary of PAS data for 80 public-supply wells sampled in 2015 and 2016 in the High Plains aquifer (data available in Arnold and others, 2020b).

The PAS assessments like this one allow for the comparison of constituent concentrations in untreated groundwater with benchmarks established for the protection of human health and for aesthetic qualities of drinking water and also provide a basis for comparison of groundwater quality among the principal aquifers.

The data collected by the NAWQA Project include chemical analyses generally not available as part of regulatory compliance monitoring, including measurements at concentrations much lower than the levels used as human-health benchmarks and measurement of constituents that can be used to trace the sources and movement of groundwater.

\section{For more information}

Technical reports and hydrologic data collected for the USGS NAWQA Project may be obtained from

\footnotetext{
NAWQA Chief Scientist

U.S. Geological Survey

12201 Sunrise Valley Drive, MS 413

Reston, VA 20192-0002

Email: nawqapublicinfo@usgs.gov

WEB: https://water.usgs.gov/nawqa/
} 